\title{
Takotsubo cardiomyopathy and pituitary apoplexy: a case report
}

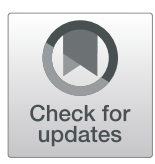

\author{
Chun Yang, Xiu Han ${ }^{*}$ D, Yuan Du and Ai-qun Ma
}

\begin{abstract}
Background: Takotsubo cardiomyopathy (TTC) has been widely recognized in recent decades and is triggered by either physical or psychological stressors.

Case presentation: A 70-year-old woman presented to the Emergency Department due to confusion, hypotension, fever, chills, and cough. She had a one-year history of diabetes insipidus. Pituitary function examination at admission revealed decreased thyroid, sex and adrenal hormones. Pituitary MRI displayed findings suggestive of nonhemorrhagic pituitary apoplexy. Electrocardiogram (ECG) revealed T-wave inversion and extended QT interval. Transthoracic echocardiogram (TTE) showed left ventricular apical dysplasia and ballooning, accompanied by reduced left ventricular ejection fraction. Coronary angiography (CAG) revealed no obvious coronary arterial stenosis. The left ventriculogram demonstrated an octopus clathrate appearance. Most ECG and TTE changes recovered 10 days later.
\end{abstract}

Conclusions: To the best of our knowledge, this is the first report of newly diagnosed $\Pi \mathrm{C}$ associated with pituitary apoplexy.

Keywords: Takotsubo cardiomyopathy, Takotsubo, Stress cardiomyopathy, Pituitary apoplexy, Hypopituitarism

\section{Background}

Takotsubo cardiomyopathy (TTC) was first described in Japanese in 1990 by Sato [1] because of the resemblance between Takotsubo (name of a Japanese octopus trap) and the left ventricular appearance during systole of the patients [2]. After the first report, the syndrome has been widely recognized. In 2001, more cases were described in English by Tsuchihashi K [3]. Since then, the disease has acquired multiple names, such as stress cardiomyopathy, apical ballooning syndrome and broken heart syndrome [4]. TTC is triggered by physical or emotional stressors and is characterized by a reduction in the left ventricular ejection fraction (LVEF) associated with a balloon-like wall motion abnormality, typical hypokinesia in the apical segment and hyperkinesia in the basal segments in the absence of significant coronary

\footnotetext{
* Correspondence: hanxiu0711@163.com

Department of Cardiovascular Medicine, First Affiliated Hospital of Xi'an Jiaotong University, Xi'an 710061, Shaanxi, China
}

artery diseases [5-7]. TTC is a transient LV dysfunction and generally recovers within a few days to weeks.

\section{Case presentation}

A 70-year-old female patient with a one-year history of diabetes insipidus was transferred to the Emergency Department of our hospital due to confusion and hypotension (minimum of $70 / 44 \mathrm{mmHg}$, maintained by dopamine). She also had fever (maximum of $39.3^{\circ} \mathrm{C}$ ), chills, and cough with a small amount of white phlegm that lasted for 2 days. The patient fainted 6 months ago and fell, and the head computed tomography $(\mathrm{CT})$ at that time demonstrated left frontal and occipital fractures accompanied by frontotemporal lobe cerebral contusion, subarachnoid and subdural haemorrhage (Fig. 1 a), and incidental pituitary micro adenoma (Fig. 1 b). She had menopause at 48 years old.

On examination, her body temperature was $37.9^{\circ} \mathrm{C}$, heart rate was $98 \mathrm{bpm}$, respiratory rate was $23 \mathrm{bpm}$, and blood pressure was $95 / 67 \mathrm{mmHg}$ (maintained by

(c) The Author(s). 2020 Open Access This article is licensed under a Creative Commons Attribution 4.0 International License, which permits use, sharing, adaptation, distribution and reproduction in any medium or format, as long as you give appropriate credit to the original author(s) and the source, provide a link to the Creative Commons licence, and indicate if changes were made. The images or other third party material in this article are included in the article's Creative Commons licence, unless indicated otherwise in a credit line to the material. If material is not included in the article's Creative Commons licence and your intended use is not permitted by statutory regulation or exceeds the permitted use, you will need to obtain permission directly from the copyright holder. To view a copy of this licence, visit http://creativecommons.org/licenses/by/4.0/ The Creative Commons Public Domain Dedication waiver (http://creativecommons.org/publicdomain/zero/1.0/) applies to the data made available in this article, unless otherwise stated in a credit line to the data. 

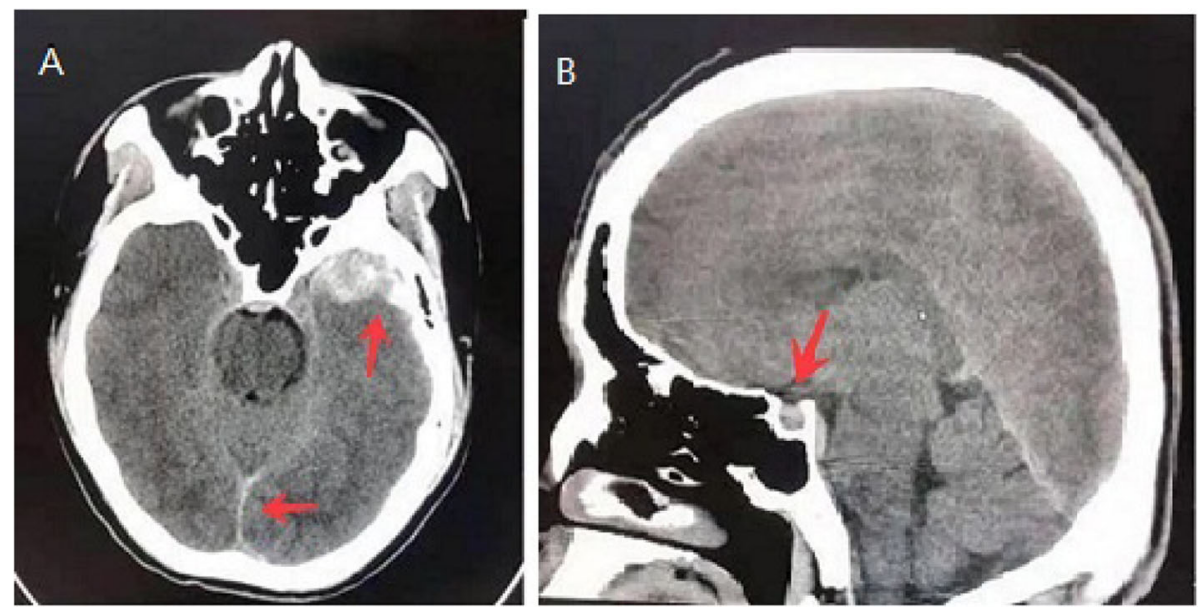

Fig. 1 Pituitary CT at trauma 6 months ago showing subarachnoid and left subdural haemorrhage (Fig. 1 a) and pituitary microadenoma (Fig. 1 b)

dopamine). Whole body physical examination showed that she had dry skin, chapped lips, pale areola, and sparse pubic and armpit hairs. On chest examination, coarse crackles were heard in both lung bases. All other physical examination results were within normal limits.

Infectious work-up showed elevated neutrophil count $\left(7.8 \times 10^{9} / \mathrm{L}\right)$ and percentage $(88 \%)$ as well as procalcitonin (PCT) at $0.291 \mathrm{ng} / \mathrm{mL}$. Respiratory syncytial virus was positive, and other viruses were negative. Chest CTshowed bilateral pulmonary congestion, interstitial fibrosis, pleural effusion, and adjacent pulmonary atelectasis versus pneumonic infiltrates. Other laboratory examinations at admission revealed that the patient had yellow urine with a specific gravity of 1.015 and a volume of $4000 \mathrm{ml}$. Serum electrolyte examination showed potassium at $2.59 \mathrm{mmol} / \mathrm{L}$, sodium at $125 \mathrm{mmol} / \mathrm{L}$, calcium at $1.83 \mathrm{mmol} / \mathrm{L}$, and phosphorus at $0.44 \mathrm{mmol} / \mathrm{L}$. Laboratory adenohypophysis function examinations documented decreased thyroid, sex and adrenal hormones (Table 1). Pituitary MR imaging performed on the day of admission revealed enlarged sella measuring $15 \mathrm{~mm} \times 10$ $\mathrm{mm} \times 9 \mathrm{~mm}$ with heterogenous high signal on coronal T2 weighted image (Fig. 2 a) and central low signal with peripheral rim enhancement on post contrast T1 weighted coronal (Fig. 2 b) and sagittal (Fig. 2 c) images causing mild compression on the optic chiasm, which is suggestive of acute pituitary apoplexy [8]. Thus, the patient was emergently managed for both pituitary apoplexy and pulmonary infection and was treated by hormone replacement therapy (adrenocortical hormone and levothyroxine sodium tablets), antibiotics (moxifloxacin and ganciclovir), ambroxol, and doxofylline.

Cardiac examination at admission showed elevated repeated brain natriuretic peptide precursor (Pro-BNP), Creactive peptide (CRP), high sensitivity $\mathrm{C}$-reactive peptide (hs-CRP) and troponin $\mathrm{T}$ (cTnT) levels (Table 2). ECG revealed T-wave inversion on the inferior and anterior walls and an extended QT interval (QT/QTc 780/ $762 \mathrm{~ms}$ ) (Fig. 3 a). Emergency bedside TTE showed left ventricular ballooning, apical dyskinesia, and abnormal diastolic function (LVEF being $36 \%$ by Simpson's method) (Fig. 4 a b c), which was considered Takotsubo cardiomyopathy. Coronary angiography (CAG) performed 2 days later found no significant coronary arterial

Table 1 Laboratory tests-pituitary function

\begin{tabular}{lll}
\hline Paraclinical tests & Value & Reference value \\
\hline Thyroid hormone & & \\
Thyrotropin (TSH) & $0.414 \mu \mathrm{lU} / \mathrm{mL}$ & $0.25-5 \mu \mathrm{IU} / \mathrm{mL}$ \\
Thyroxine (T4) & $2.22 \mu \mathrm{g} / \mathrm{dL}$ & $4.2-13.5 \mu \mathrm{g} / \mathrm{dL}$ \\
Triiodothyrosine (T3) & $0.550 \mathrm{ng} / \mathrm{ml}$ & $0.8-2.2 \mathrm{ng} / \mathrm{ml}$ \\
Free-T4 (FT4) & $4.98 \mathrm{pmol} / \mathrm{L}$ & $9.05-25.5 \mathrm{pmol} / \mathrm{L}$ \\
Free-T3 (FT3) & $3.19 \mathrm{pmol} / \mathrm{L}$ & $2.91-9.08 \mathrm{pmol} / \mathrm{L}$ \\
Sex hormone & & \\
Luteinizing hormone (LH) & $<0.1 \mathrm{mlU} / \mathrm{mL}$ & $7.7-58.5 \mathrm{mlU} / \mathrm{mL}$ \\
Follicle-stimulating hormone (FSH) & $0.927 \mathrm{mlU} /$ & $25.8-134.8 \mathrm{mlU} /$ \\
& $\mathrm{mL}$ & $\mathrm{mL}$ \\
Pituitary prolactin (PRL) & $0.24 \mathrm{ng} / \mathrm{ml}$ & $4.79-23.3 \mathrm{ng} / \mathrm{ml}$ \\
Oestradiol (E2) & $<18.4 \mathrm{pmol} / \mathrm{L}$ & $<18.4-201 \mathrm{pmol} /$ \\
& & $\mathrm{L}$ \\
Progesterone (P) & $0.16 \mathrm{nmol} / \mathrm{L}$ & $0.3-2.5 \mathrm{nmol} / \mathrm{L}$ \\
Testosterone (T) & $<0.087 \mathrm{nmol} /$ & $0.101-1.42 \mathrm{nmol} /$ \\
& $\mathrm{L}$ & $\mathrm{L}$ \\
Adrenal hormone & & $7.2-63.3 \mathrm{pg} / \mathrm{ml}$ \\
Adrenocorticotropic hormone & $<1.0 \mathrm{pg} / \mathrm{ml}$ & \\
(ACTH) & & $5.0-28.0 \mu \mathrm{g} / \mathrm{dl}$ \\
COR & & \\
\hline
\end{tabular}




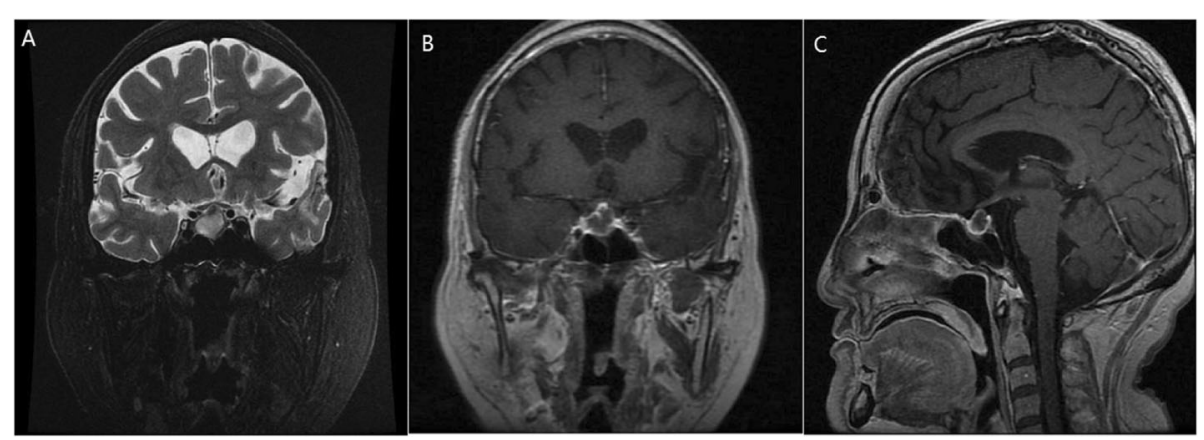

Fig. 2 Pituitary MRI at admission showed an enlarged pituitary gland with heterogenous high signal on coronal T2 weighted image (Fig. 2 a) and central low signal with peripheral rim enhancement on post contrast T1 weighted coronal (Fig. 2 b) and sagittal (Fig. 2 c) images causing mild compression on the optic chiasm, which is suggestive of acute pituitary apoplexy

stenosis (Fig. 5), but left ventricular angiogram demonstrated the typical apical LV wall motion abnormalities and a peculiarly shaped LV (a round bottom and narrow neck), resembling the type of bottle used in Japan for trapping octopus (Figs. 6). Therefore, the patient was diagnosed with Takotsubo cardiomyopathy and treated with angiotensin converting enzyme inhibitor (ACEI), $\beta$ blocker and L-carnitine.

At 3 days after treatment, the patient's vital signs were stable, her body temperature was $36.14^{\circ} \mathrm{C}$, her heart rate was $62 \mathrm{bpm}$, her respiratory rate was $18 \mathrm{bpm}$, and her blood pressure was $124 / 72 \mathrm{mmHg}$.

At 10 days after treatment, Pro-BNP and cTnT levels were reduced to $500.8 \mathrm{pg} / \mathrm{mL}$ and $0.01 \mathrm{ng} / \mathrm{mL}$, respectively (Table 1). ECG revealed that the T-wave inversion partially recovered, and the QT interval returned to normal, with QT/QTc being 440/350 ms (Fig. 3b). TTE showed recovered LV apical ballooning and normal wall motion at 10 days after treatment (Fig. 4 d).

Table 2 Laboratory tests-cardiac function

\begin{tabular}{|c|c|c|}
\hline Paraclinical tests & Value & $\begin{array}{l}\text { Reference } \\
\text { value }\end{array}$ \\
\hline Brain natriuretic peptide (Pro-BNP) & & $0-125 \mathrm{pg} / \mathrm{ml}$ \\
\hline 2018-01-06 & $3069 \mathrm{pg} / \mathrm{ml}$ & \\
\hline 2018-01-09 & $3037 \mathrm{pg} / \mathrm{ml}$ & \\
\hline 2018-01-12 & $6178 \mathrm{pg} / \mathrm{ml}$ & \\
\hline 2018-01-19 & $\begin{array}{l}500.8 \mathrm{pg} / \\
\mathrm{ml}\end{array}$ & \\
\hline $\mathrm{C}$ reactive protein (CRP) & $11.1 \mathrm{mg} / \mathrm{L}$ & $0-10 \mathrm{mg} / \mathrm{L}$ \\
\hline $\begin{array}{l}\text { Hypersensitive } C \text { reactive protein (hs- } \\
\text { CRP) }\end{array}$ & $>10 \mathrm{mg} / \mathrm{L}$ & $0-3 \mathrm{mg} / \mathrm{L}$ \\
\hline Troponin T (cTnT) & & $0-0.014 \mathrm{ng} / \mathrm{ml}$ \\
\hline 2018-01-06 & $0.046 \mathrm{ng} / \mathrm{ml}$ & \\
\hline 2018-01-12 & $0.010 \mathrm{ng} / \mathrm{ml}$ & \\
\hline
\end{tabular}

Thirteen days after treatment, the patient suffered new abdominal pain, and her examination showed positive Murphy's sign. Routine blood tests showed elevated neutrophil counts $(8.86 \times 10[9] / \mathrm{L})$ and percentages $(83 \%)$. Re-examination of Pro-BNP at the same time showed normal Pro-BNP levels. Her abdominal ultrasound was suggestive of acute cholecystitis. Thus, the patient was managed conservatively with antibiotics, and symptoms of acute cholecystitis resolved after 3 days.

At 2 months after treatment, there were no left ventricular apical ballooning or wall motion abnormalities, with LVEF at $63 \%$ by Simpson's method (Figs. $4 \mathrm{e}$ and $\mathrm{f}$ ).

\section{Discussion}

The mechanisms of TTC are not clear but are likely related to increased plasma concentrations of catecholamines because most cases have recent excessive physical or psychological stressors $[9,10]$. TTC occurs mainly in postmenopausal women [11]. Pelliccia F. et al. [12] found that $86 \%$ of TCC cases were women, and only $14 \%$ were men. These results are line with Templin C et al. [13], who found that $79.1 \%$ of TCC occurs in women over 50 years of age.

Previous studies evaluating the risk factors for TTC have suggested that the syndrome is mainly associated with a stressful event, surgery or acute clinical illness such as COPD, migraine, affective disorders, cancer, neurological disease, and psychiatric disorders but rarely with cardiovascular risk factors [13-15]. Mario $S$ et al. [16] reported a case in which hyponatraemia can trigger Takotsubo cardiomyopathy. Either emotional or physical stress can trigger TCC development. Studies [17] have revealed that $56-89 \%$ of TTC patients suffer from stressful events $(25-47 \%$ from emotional stress and $23-51 \%$ from physical stress), and $11-44 \%$ of TTC patients do not suffer from stressful events. A recent meta-analysis [12] of 1109 


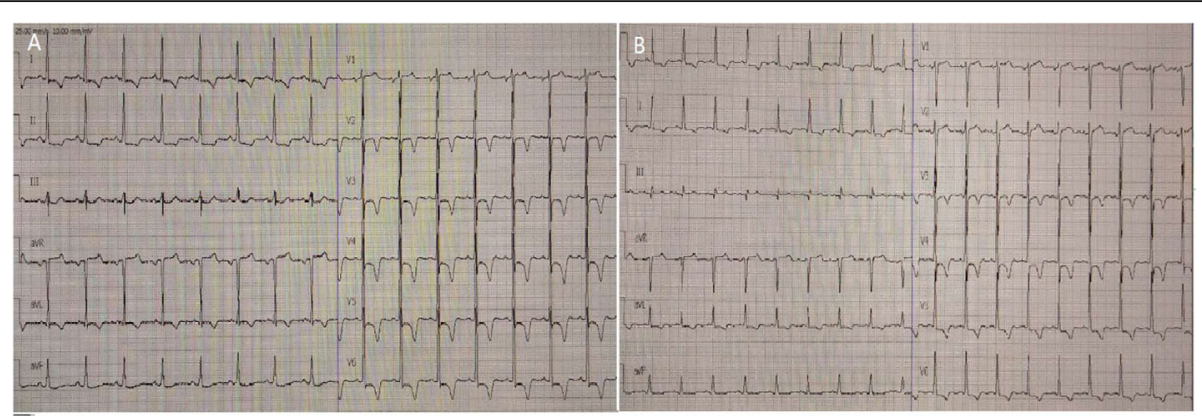

Fig. 3 a ECG at admission showing T-wave inversion on the inferior and anterior wall and extended QT interval. b ECG at 10 days after treatment, showing that T-wave inversion partially recovered and QT interval returned to normal

TTC patients showed that $39 \%$ patients had emotional stressors, $35 \%$ patients had physical stressors, and $17 \%$ patients had no stressors. In addition, the study also showed that common comorbidities of TTC patients were psychiatric disorders (24\%), pulmonary diseases (15\%), malignancies $(10 \%)$, neurological disorders (7\%), chronic kidney disease (7\%), and thyroid diseases (6\%). A systematic review [18] identified that bacterial sepsis was the most frequent cause of TTC. A number of TTC studies $[13,18,19]$ found that $3-23 \%$ of cases were associated with surgical operation and perioperative conditions. Manfredini $\mathrm{R}$ et al. [20] conducted a meta-analysis on the relationship between respiratory diseases and TTC and showed that chronic obstructive pulmonary disease
(COPD), acute asthmatic attack and pulmonary embolism may trigger TTC.

In this study, we report the first case of Takotsubo cardiomyopathy with hypopituitarism in the setting of pituitary apoplexy and provide evidence to support that pituitary apoplexy may be associated with myocardial stunning. The old woman suffered diabetes insipidus that may be related to prior head trauma, and cranial $\mathrm{CT}$ at that time revealed subarachnoid and subdural haemorrhage and pituitary micro adenoma. However, her admission investigations showed that she had decreased sex hormones, thyroid hormones and ACTH levels, hypouria, increased urine volume, and reduced electrolyte levels, suggesting that both anterior hypophysis and neurohypophysis functions were affected. The
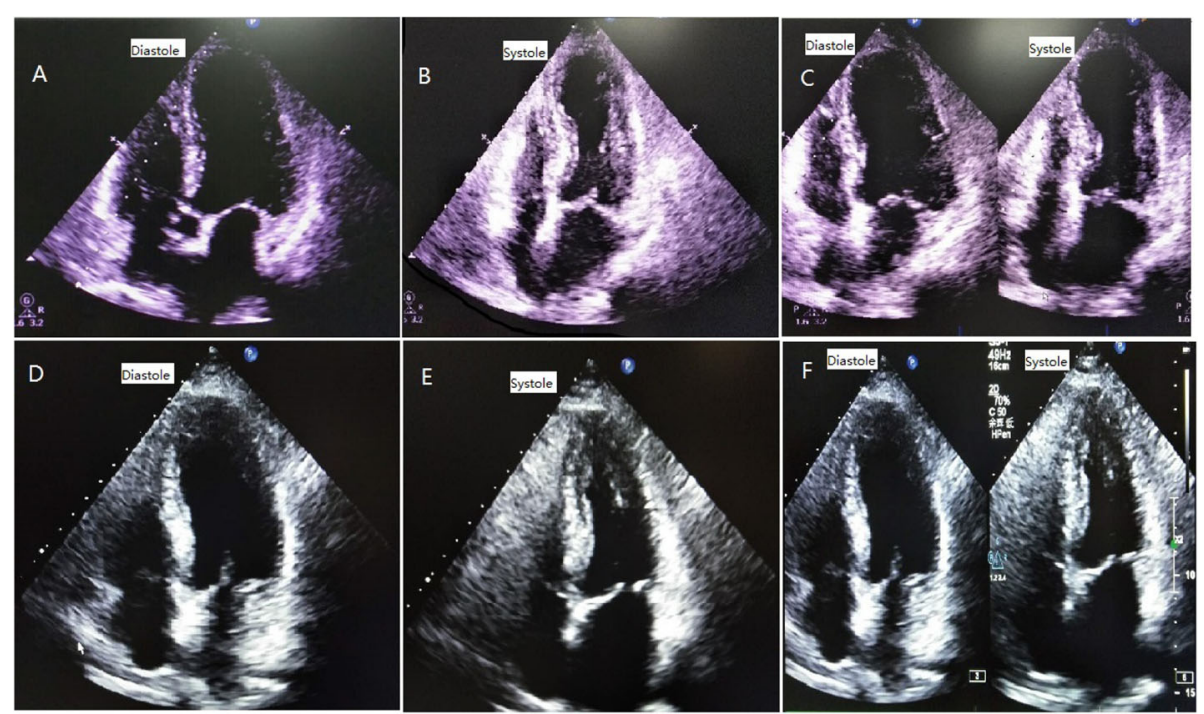

Fig. 4 a b c Four-chamber view of TTE at admission showing ventricular "ballooning" caused by apical dyskinesis. d Four-chamber view of TTE at 7 days after treatment showing that LV apical "ballooning" was recovered. e f Four-chamber view of TTE two months later, showing no LV apical "ballooning" or wall motion abnormalities 


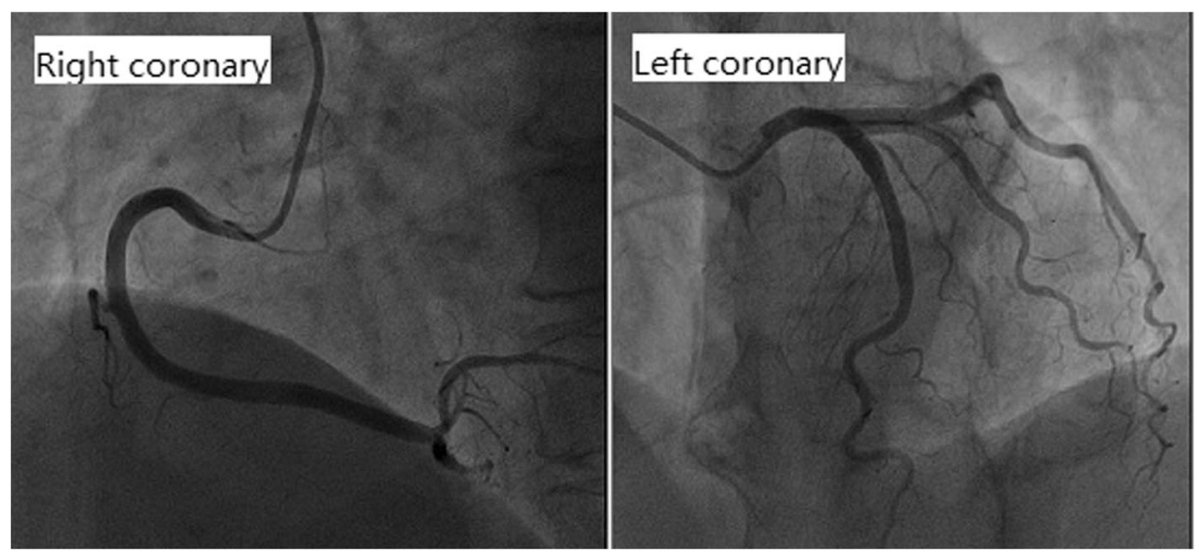

Fig. 5 CAG demonstrating no significant coronary obstructive stenosis (both right and left coronary were nomal)

patient had suffered significant stressor such as fever and pulmonary infection before the onset of the symptoms and had emergency signs and symptoms such as hypotension and unconsciousness at the presentation, all of which conform to acute pituitary apoplexy.

The patient's CAG showed no obvious abnormality, but the left ventricular angiogram revealed typical apical ballooning and wall motion abnormalities. TTE at admission showed LV apical ballooning, abnormal systolic function, and LVEF of $36 \%$ by Simpson's method. In addition, the 70-year-old patient had elevated Pro-BNP, inverted $\mathrm{T}$-wave and extended QT interval, all of which met the diagnostic criteria of TTC. Thus, we concluded that TTC was induced by pituitary crisis. After 10 days of treatment, the level of Pro-BNP was reduced, and Twave inversion and QT interval extension disappeared in the ECG. In particular, there were no LV apical ballooning or left ventricular wall motion abnormalities, which suggested the recovery of the affected myocardium and explicit TTC diagnosis.
Re-examination of Pro-BNP during the attack of acute cholecystitis was in the normal range, which further confirmed that TTC was triggered by hypopituitary crisis rather than infection.

Recently, there has been increasing evidence to suggest the occurrence of TTC in patients with oestrogen deficiency, thyroid dysfunction or adrenal insufficiency [10]. The patient we describe suffered from TTC accompanied by acute pituitary apoplexy on the basis of both anterior hypophysis and neurohypophysis dysfunction. However, the mechanism remains unclear.

\section{Conclusions}

Takotsubo cardiomyopathy is an increasingly recognized condition. Here, we report the first case of Takotsubo cardiomyopathy with pituitary apoplexy in a postmenopausal woman, significantly supporting the recognition that physical stress can trigger TTC.

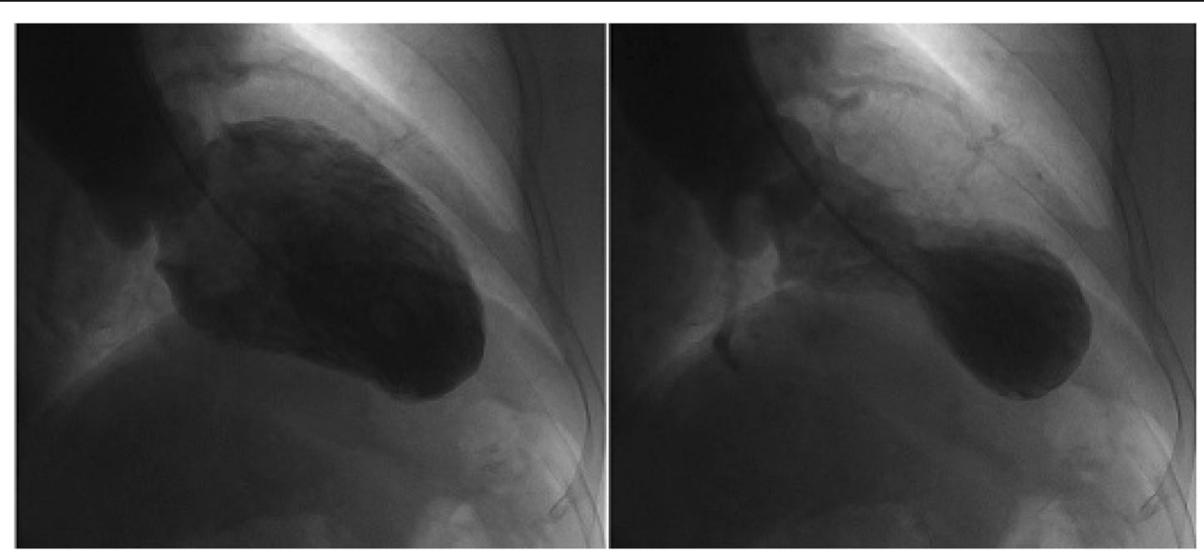

Fig. 6 Left ventricular angiogram demonstrating that the LV had a peculiar shape (a round bottom and narrow neck), which resembles the type of bottle used in Japan for trapping octopus 


\section{Abbreviations}

TTC: Takotsubo cardiomyopathy; ECG: Electrocardiogram; TTE: Transthoracic echocardiogram; LVEF: Left ventricular ejection fraction; PCT: Procalcitonin; CAG: Coronary angiography; ACEl: Angiotensin converting enzyme inhibitor

\section{Acknowledgements}

Not applicable.

\section{Authors' contributions}

$H X$ and YC designed the study. HX drafted the manuscript. DY participated in the entire treatment process. MAQ and YC participated in the manuscript revision process. All authors have read and approved the final manuscript.

\section{Funding}

This research did not receive any specific grant from funding agencies in the public, commercial, or not-for-profit sectors.

\section{Availability of data and materials}

All the data supporting our findings are contained within the manuscript

\section{Ethics approval and consent to participate}

Not applicable.

\section{Consent for publication}

Written informed consent was obtained from the patient for publication of this case report and any accompanying images.

\section{Competing interests}

The authors declare that they have no competing interests.

Received: 22 April 2019 Accepted: 11 May 2020

Published online: 19 May 2020

\section{References}

1. Dote K, Sato H, Tateishi H, Uchida T, Ishihara M. Myocardial stunning due to simultaneous multivessel coronary spasms: a review of 5 cases. J Cardiol. 1991:21:203-14.

2. Ryohei OL, Menezes F. Takotsubo cardiomyopathy systematic review: pathophysiologic process, clinical presentation and diagnostic approach to Takotsubo cardiomyopathy. Int J Cardiol. 2016;209:196-205.

3. Kazufumi T, Kenji U, Tatsuro U, Nobuhiro O, Kazuo K, Mafumi O, Minoru Y, Shunichi M, Kazuo H, Hisao O, et al. Transient left ventricular apical ballooning without coronary artery stenosis: a novel heart syndrome mimicking acute myocardial infarction. Angina pectoris-myocardial infarction investigations in Japan. J Am CollCardiol. 2001;38:11-8.

4. Sharkey SW, Lesser JR, Maron MS, Maron BJ. Why not just call it Takotsubo cardiomyopathy: a discussion of nomenclature. J Am Coll Cardiol. 2011;5: 1496-7

5. Akashi YJ, Nef HM, Lyon AR. Epidemiology and pathophysiology of Takotsubo syndrome. Nat Rev Cardiol. 2015;12:387-97.

6. Redfors B, Shao YZ, Ali A, Omerovic E. Current hypotheses regarding the pathophysiology behind the Takotsubo syndrome. Int J Cardiol. 2014;177: 771-9.

7. Summers MR, Prasad A. Takotsubo cardiomyopathy: definition and clinical profile. Heart Fail Clin. 2013:9:111-22.

8. Goyal P, Utz M, Gupta N, Kumar Y, Mangla M, Gupta S, Mangla R. Clinical and imaging features of pituitary apoplexy and role of imaging in differentiation of clinical mimics. Quant Imaging Med Surg. 2018;8(2):219.

9. Jiang DM, Sunc ZW, Han J. Tako-tsubo cardiomyopathy after a quarrel. Afr Health Sci. 2015;15:1349-53.

10. Gupta S, Goyal P, Idrees S, Aggarwal S, Bajaj D, Mattana J. Association of Endocrine Conditions with Takotsubo cardiomyopathy: a comprehensive review. J Am Heart Assoc. 2018;7(19):e009003.

11. Schneider B, Athanasiadis A, Sechtem U. Gender-related differences in Takotsubo cardiomyopathy. Heart Fail Clinic. 2013;9:137-46

12. Pelliccia F, Parodi G, Greco C, Antoniucci D, Brenner R, Bossone E, Cacciotti L, Capucci A, Citro R, Delmas C, et al. Comorbidities frequency in Takotsubo syndrome: an international collaborative systematic review including 1109 patients. Am J Med. 2015;128:654

13. Templin C, Ghadri JR, Diekmann J, Napp LC, Bataiosu DR, Jaguszewski M, Cammann VL, Sarcon A, Geyer V, Neumann CA, et al. Clinical features and outcomes of Takotsubo (stress) cardiomyopathy. N Engl J Med. 2015;373: 929-38.

14. Tornvall P, Collste O, Ehrenborg E, Petterson HJ. A case-control study ofrisk markers and mortality in Takotsubo stress cardiomyopathy. J Am Coll Cardiol. 2016;67:1931-6.

15. El-Sayed AM, Brinjikji W, Salka S. Demographic and co-morbid predictors of stress (Takotsubo) cardiomyopathy. Am J Cardiol. 2012;110:1368-72.

16. Mario S, Vasco D, Ana M, Catarina G, Andre L. Hyponatremia - an unusual trigger of Takotsubo cardiomyopathy. Rev Port Cardiol 2011;30(11):845-848.

17. Toshiaki I, Hideo Y, Hiroki M, Hiroyuki T, Tetsuro U, Hiromasa H, Kiyohide F. Out-of-hospital versus in-hospital Takotsubo cardiomyopathy: analysis of 3719 patients in the diagnosis procedure combination database in Japan. Int J Cardiol. 2014;176:413-7.

18. Simone C, Costantino C, Mariarosaria A, Hutan A, Sian H, Thanos A. Takotsubo cardiomyopathy and sepsis: a systematic review. Angiology. 2017;68(4):288-303.

19. Eugene A, Hessel II. Takotsubo cardiomyopathy and its relevance to anesthesiology: anarrative review. Can J Anesth. 2016;63:1059-74.

20. Manfredini R, Fabbian F, Giorgi AD, Pala M, Menegatti AM, Parisi C, Misurati E, Tiseo R, Gallerani M, Salmi R, Bossone E. Heart and lung, a dangerous liaison-Takotsubo cardiomyopathy and respiratory diseases: a systematic review. World J Cardiol. 2014:6:338-44.

\section{Publisher's Note}

Springer Nature remains neutral with regard to jurisdictional claims in published maps and institutional affiliations.

\section{Ready to submit your research? Choose BMC and benefit from:}

- fast, convenient online submission

- thorough peer review by experienced researchers in your field

- rapid publication on acceptance

- support for research data, including large and complex data types

- gold Open Access which fosters wider collaboration and increased citations

- maximum visibility for your research: over $100 \mathrm{M}$ website views per year

At $\mathrm{BMC}$, research is always in progress.

Learn more biomedcentral.com/submissions 